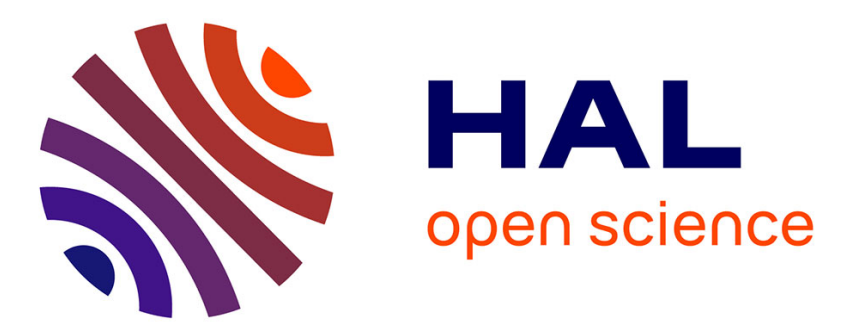

\title{
Spectroscopic analysis of "MgAlON" spinel powders: influence of nitrogen content
}

Olivier Morey, Patrice Goeuriot, Philippe Grosseau, Bernard Guilhot, Mourad Benabdesselam, Philibert Iacconi

\section{- To cite this version:}

Olivier Morey, Patrice Goeuriot, Philippe Grosseau, Bernard Guilhot, Mourad Benabdesselam, et al.. Spectroscopic analysis of "MgAlON" spinel powders: influence of nitrogen content. Solid State Ionics, 2003, 159 (3-4), pp.381-388. 10.1016/S0167-2738(02)00918-9 . emse-00520243

HAL Id: emse-00520243

https://hal-emse.ccsd.cnrs.fr/emse-00520243

Submitted on 15 Oct 2010

HAL is a multi-disciplinary open access archive for the deposit and dissemination of scientific research documents, whether they are published or not. The documents may come from teaching and research institutions in France or abroad, or from public or private research centers.
L'archive ouverte pluridisciplinaire HAL, est destinée au dépôt et à la diffusion de documents scientifiques de niveau recherche, publiés ou non, émanant des établissements d'enseignement et de recherche français ou étrangers, des laboratoires publics ou privés. 


\title{
Spectroscopic analysis of "MgAlON" spinel powders: influence of nitrogen content
}

\section{Olivier Morey(1), PATrice Goeuriot ${ }^{(1)}$, PhilipPe Grosseau $^{2}{ }^{*} *$, Guilhot BERNARD $^{(2)}$, MOURAD BENABDESSELAM(3) ${ }^{(3 H I L I B E R T ~ I A C C O N I}{ }^{(3)}$}

(1) Ecole Nationale Supérieure des Mines de Saint Etienne, Centre SMS ; Département MPE ; PECM, UMR CNRS 5146, 158 Cours Fauriel ; 42023 Saint-Étienne Cedex 2, France

(2) Ecole Nationale Supérieure des Mines de Saint Etienne, Centre SPIN ; Département PMMC ; LPMG, UMR CNRS 5148, 158 Cours Fauriel ; 42023 Saint-Étienne Cedex 2, France

(3) Université de Nice-Sophia Antipolis, LPES, EA1174, Parc Valrose, o6108, Nice Cedex 2, France

\begin{abstract}
The thermoluminescence (TL) and fluorescence spectra of magnesium aluminium oxynitride "MgAlON" and magnesium aluminate $\mathrm{MgAl}_{2} \mathrm{O}_{4}$ spinel powders have been analysed. Two broad peaks at about 100 and $300{ }^{\circ} \mathrm{C}$ appear in the TL spectra of $\mathrm{MgAl}_{2} \mathrm{O}_{4}$ and seem to be related to electron and hole release from $\left[\mathrm{Al}_{\mathrm{Mg}}{ }^{\vee}\right]$ and $\left[\mathrm{Mg}_{\mathrm{Al}^{\prime}}\right]$ traps, respectively. The intensity of each peak strongly depends on the nature of the annealing atmosphere (neutral, oxidizing or reducing). TL spectral analyses have shown the presence of two intense emissions at 520 and $690 \mathrm{~nm}$ attributed to the $\mathrm{Mn}^{2+}$ and $\mathrm{Cr}^{3+}$ emitting centers, respectively. A study on $\mathrm{MgAl}_{2} \mathrm{O}_{4}$ is used as a reference for MgAlON powders, which can be considered as a solid solution derived from magnesium aluminate. Disturbance in the emission spectrum of $\mathrm{Cr}^{3+}$ is clearly observed with the nitrogen/oxygen substitution.
\end{abstract}

Keywords:

MgAlON; Thermoluminescence; Fluorescence; $\mathrm{MgAl}_{2} \mathrm{O}_{4}$

\section{Introduction}

A solid solution containing magnesium, aluminium, oxygen and nitrogen elements has been for the first time observed on the SiAlON system [1]. More recently, Sun et al. [2] extended the knowledge of the system $\mathrm{Mg}-\mathrm{Al}-\mathrm{O}-\mathrm{N}$. Magnesium aluminium oxynitride can be easily synthesised by solid state reaction between $\mathrm{AlN}, \mathrm{MgO}$ and $\alpha-\mathrm{Al}_{2} \mathrm{O}_{3}$, and such a solid solution has been previously obtained by Willems [3] at $1400{ }^{\circ} \mathrm{C}$. Granon et al. [4] have given some details on the reactivity in this system. In our case, single MgAlON phase was obtained after an appropriate thermal treatment of these mixed starting powders at $1450{ }^{\circ} \mathrm{C}$ for $9 \mathrm{~h}$ under static atmosphere of nitrogen (grade $\mathrm{U}$ ) at $0.1 \mathrm{MPa}$.

The study of the MgAlON compounds must be completed by the study of $\mathrm{MgAl}_{2} \mathrm{O}_{4}$ and $\gamma \mathrm{AlON}$ materials, which are the two limits for the MgAlON solid solution.

A commercial $\mathrm{MgAl}_{2} \mathrm{O}_{4}$ powder $(\% \mathrm{~N}=0)$ was selected as a reference material. This powder (labelled $\mathrm{S} 30 \mathrm{Cr}$ from Baikowski) obeys the formula $\mathrm{Mg}_{0.969} \mathrm{Al}_{2.021} \mathrm{O}_{4}$, which is very close to the ideal stoichiometric composition. Point defects in $\mathrm{MgAl}_{2} \mathrm{O}_{4}$ have been widely studied $[5,6,7$, $8,9,10,11,12,13,14,15,16,17$ and 18] either by thermostimulated methods such as

\footnotetext{
"Corresponding author : grosseau@emse.fr
} 
thermoluminescence (TL) and thermally stimulated conductivity (TSC) or by spectroscopic techniques such as electronic spin resonance (ESR) and UV fluorescence. No data have been published on MgAlON compounds. As a result, this study is firstly focused on $\mathrm{MgAl}_{2} \mathrm{O}_{4}$ in order to disregard the influence of the nitrogen content in the MgAlON derived solid solution. By comparing the results obtained for $\mathrm{MgAl}_{2} \mathrm{O}_{4}$ and $\mathrm{MgAlON}$, we will try to understand the evolution of point defects according to the nitrogen content.

YAlON material was also studied. In this material, all the cationic sites of the spinel solid solution are occupied by $\mathrm{Al}^{3+}$ ions [19]. $\gamma \mathrm{AlON}$ compounds are obtained by reaction between $\mathrm{AlN}$ and $\mathrm{Al}_{2} \mathrm{O}_{3}$ at $1700{ }^{\circ} \mathrm{C}$ under static nitrogen (grade $\mathrm{U}$ ) at atmospheric pressure.

\section{Crystallochemical properties of the spinel structure}

One of the particular characteristics of the $\mathrm{MgAl}_{2} \mathrm{O}_{4}$ spinel structure ( $F d 3 m$ space group) is the possible existence of a disorder in the cationic lattice. This disorder is due to permutation between some of $\mathrm{Mg}^{2+}$ cations and some of $\mathrm{Al}^{3+}$ ions which normally are located in tetrahedral and octahedral sites, respectively. As a result, some divalent $\mathrm{Mg}^{2+}$ ions are present in sites of octahedral symmetry, whereas some of trivalent $\mathrm{Al}^{3+}$ ions are in tetrahedral position. The ideal structure, obtained when there is no permutation, is called "normal spinel" and can be observed from natural $\mathrm{MgAl}_{2} \mathrm{O}_{4}$ materials [20]. On the other hand, a certain degree of disorder is observed in synthesized samples.

The MgAlON compounds have also the spinel structure. However, during the synthesis process, the introduction of aluminium nitride leads to modifications of the original spinel cell: firstly, the nitrogen element brings a covalent character to the structure which modifies its crystallochemical properties, secondly, the oxygen/nitrogen substitution has also a large impact on cationic and anionic sublattices. We will try to identify and explain the consequences of the anionic substitution by making use of spectroscopic techniques.

\section{Experimental conditions}

\section{III.1. Powders preparation}

Three mixed powders, denoted $\mathrm{A}_{0}, \mathrm{~B}_{0}, \mathrm{C}_{\mathrm{o}}$ with different molecular percentages of starting materials, were prepared as follows (Table 1): a mixture of $\mathrm{AlN}, \mathrm{MgO}$ and $\mathrm{Al}_{2} \mathrm{O}_{3}$ was placed in an azeotropic solvent (slurry contains $60 \mathrm{wt} . \%$ of powders) with phosphoric ester and polyvinylpyrrolidone PVP as dispersant agents (respectively 1.1 and 0.9 wt.\%). Table 2 gives information about the starting powders, especially impurities. The de-agglomeration was achieved by an ultrasonic treatment of 2 min and the homogenisation of the slurry was then realized on roller bearings during $24 \mathrm{~h}$. The two following steps were a soft drying of the slurry at $80{ }^{\circ} \mathrm{C}$ and sieving at $200 \mu \mathrm{m}$. Lastly, the preparation of samples was followed by a thermal treatment in a graphite furnace at $1450^{\circ} \mathrm{C}$ for $9 \mathrm{~h}$ under nitrogen (grade U) static atmosphere (atmospheric pressure). The materials obtained after this treatment are called A, $\mathrm{B}$ and $\mathrm{C}$. The concentrations of metal impurities measured in these products are reported in Table 3.

In order to allow the comparison with the other products, the industrial powder $\mathrm{S} 3 \mathrm{OCr}$ also underwent a thermal treatment. Temperature and duration of this thermal treatment were similar to those used to synthesize MgAlON compounds $\left(1450{ }^{\circ} \mathrm{C}-9 \mathrm{~h}\right.$ ) but four different atmospheres were used: two neutral ones (pure argon and nitrogen) and two reducing ones (pure hydrogen and an argon-hydrogen (10\%) mixture). All the gases used were of U grade $\left(<5 \mathrm{ppm} \mathrm{O}_{2}\right.$ and $\left.\mathrm{H}_{2} \mathrm{O}\right)$.

\section{II.2. Thermoluminescence (TL)}

A small amount of powder (roughly $3 \mathrm{mg}$ ) was deposited on an aluminium cupel by the technique of acetone sedimentation in order to obtain a thin homogeneous layer of powder. Irradiation was performed at room temperature with a UV low pressure mercury lamp working at $\lambda=254 \mathrm{~nm}(4.89 \mathrm{eV})$, the excitation duration was $90 \mathrm{~s}$. TL measurements were achieved at a heating rate of $1{ }^{\circ} \mathrm{C} / \mathrm{s}$ from room temperature up to $500{ }^{\circ} \mathrm{C}$. 
Two photomultipliers were used to monitor the TL signal (2018B with S13 photocathode between 200 and $600 \mathrm{~nm}$ and XP1017 with S20R photocathode between 300 and $850 \mathrm{~nm}$ ). Ten minutes were required between the end of irradiation and the TL readout beginning in order to eliminate any phosphorescence signal.

\section{III.3. TL spectral analysis (OMA)}

The TL spectral analysis was performed for powders irradiated during 10 min with a deuterium UV lamp (with a spectral range from 200 to $400 \mathrm{~nm}$ ). During the heating of the solid, which was realized at a heating rate of $0.5{ }^{\circ} \mathrm{C} / \mathrm{s}$, an optical fibre bundle located just above the sample collected the emitted signal and sent it to a spectrophotometer containing CCD sensors. This technique also called "optical multichannel analyser" (OMA), is a powerful tool which allows to obtain the emission spectra at any temperature.

\section{III.4. Fluorescence}

Emission and excitation spectra were obtained, at room temperature, with a $450-\mathrm{W}$ Xenon arc lamp.

\section{III.5. Fourier-transform infrared spectroscopy (FTIR)}

Infrared spectra were recorded at room temperature on a Digilab FTS185 spectrophotometer in the domain $400-4000 \mathrm{~cm}^{-1} .1 \mathrm{mg}$ of powder was mixed with potassium bromide $\mathrm{KBr}$ and then pressed into pellet. The dispersion of $\mathrm{KBr}$ is required in order to optimize the resolution of broad peaks.

\section{Results and discussion}

\section{IV.1. Formulation and XRD measurements}

In order to determine their chemical compositions, the four compounds $\mathrm{A}, \mathrm{B}, \mathrm{C}$, and $\mathrm{S} 3 \mathrm{OCr}$ were characterized by Inductively Coupled Plasma/Atomic Emission spectroscopy analysis (ICP-AES) and by X-ray fluorescence. As a result, expanded formulae, lattice parameter measured at room temperature $\left(a_{\text {oexp }}\right)$ and grain size of the four studied compounds are reported in Table 4. The grain size was measured by Scanning Electron Microscopy (SEM) analysis.

The values of the $a_{\text {oexp }}$ parameter are measured $( \pm 0.0003 \mathrm{~nm})$ and compared to the $a_{\text {ocalc }}$ values obtained from the equation developed in the text (Section IV).

The measured lattice parameters $a_{\text {oexp }}$ were in good agreement with the calculated lattice parameters $a_{\text {ocalc }}$ given by the formula proposed by Granon et al. [4]:

$$
\left.\mathrm{a}_{\text {0calc }}(\mathrm{nm})=079+0.0375[\mathrm{MgO}]+0.0150[\mathrm{AlN}]\right]
$$

where the $[\mathrm{MgO}]$ and $[\mathrm{AlN}]$ concentrations are in mol\%.

\section{IV.2. TL results}

Figure 1 shows the TL curves obtained for S30Cr powder before and after annealing under different atmospheres. One can notice that the unannealed sample and the annealed one under reducing conditions exhibit no TL signal (Figure 1).

Two intense glow peaks are clearly observed on material obtained after annealing under neutral and oxidizing atmospheres at about 100 and $300{ }^{\circ} \mathrm{C}$. These peaks have been previously observed on different synthesized $\mathrm{MgAl}_{2} \mathrm{O}_{4}$ samples [5, 6, 7 and 8]. TL peaks are provoked by detrapping of charge carriers. The TL peak at about $100{ }^{\circ} \mathrm{C}$ has been related to electron release from the [AlMgV] trap [7 and 8], whereas the other is due to hole release from the $\left[\mathrm{MgAl}^{\prime}\right]$ trap [7 and 8]. The existence of these two sites is in agreement with the cationic disorder characteristic of the spinel structure [15].

TL spectral analyses of $\mathrm{MgAl}_{2} \mathrm{O} 4$ materials were performed at a heating rate of $0.5{ }^{\circ} \mathrm{C} / \mathrm{s}$. The most intense signal was obtained for sample annealed under nitrogen flow (Figure 2). Two main emission bands were clearly observed at 520 and $700 \mathrm{~nm}$. They appeared at 70 and $230^{\circ} \mathrm{C}$, as indicated in Figure 2. The difference between the temperature of TL peaks (100 and $300{ }^{\circ} \mathrm{C}$ ) and the temperatures obtained by spectral analysis $\left(70\right.$ and $230{ }^{\circ} \mathrm{C}$ ) is due to the 
difference between the heating rates (respectively 1 and $0.5{ }^{\circ} \mathrm{C} / \mathrm{s}$ ). TL spectral emission is related to the recombination of detrapped charge carriers. The emission band centered at 520 $\mathrm{nm}(2.38 \mathrm{eV})$ is attributed to divalent manganese ions substituted for magnesium ions in tetrahedral sites [9 and 11]. The second emission is more complex. It is located at about 700 $\mathrm{nm}(1.77 \mathrm{eV})$ and presents also an emission line at $690 \mathrm{~nm}$. Such an emission is characteristic of trivalent chromium ions substituted for aluminium cations in octahedral sites [5 and 6]. These results are consistent with ICP-AES analysis which shows the presence of $\mathrm{Mn}$ and $\mathrm{Cr}$ impurities (Table 3).

The nuclear magnetic resonance measurements (NMR) of ${ }^{27} \mathrm{Al}$ confirm the presence of an antisite disorder between $\mathrm{Mg}$ and $\mathrm{Al}$ on initial $\mathrm{MgAl}_{2} \mathrm{O}_{4}$ powder [21]. Thus, $\left[\mathrm{Mg}_{\mathrm{Al}}{ }^{\prime}\right]$ and $\left[\mathrm{Al}_{\mathrm{Mg}}{ }^{\vee}\right]$ defects exist in this initial powder and probably act as hole and electron traps, respectively. The TL emission can thus be the result of radiative recombination of detrapped charges with impurities such as $\mathrm{Mn}^{2+}$ and $\mathrm{Cr}^{3+}$ ions. One can notice that Tijero and Ibarra [9] have shown that the degree of disorder in $\mathrm{MgAl}_{2} \mathrm{O}_{4}$ can be measured from $\mathrm{Cr}^{3+}$ and $\mathrm{Mn}^{2+}$ luminescence characteristics. The absence of TL signal for the initial powder is probably due to the small size of grains for this unannealed sample. For $\mathrm{MgAl}_{2} \mathrm{O}_{4}$ powders annealed under reducing atmosphere, it can be assumed that, consecutively to the reducing thermal treatments, manganese and chromium ions, which normally act as radiative recombination centers, or any other chemical impurity, are stabilized in valence states which do not allow any radiative recombination, explaining thus the absence of TL peak. Because it contains a small amount of oxygen $\left(\left[\mathrm{O}_{2}\right]<5 \mathrm{ppm}\right)$, the "neutral" gas can have the same effect as oxidizing atmosphere.

TL experimentations have also been carried out on the oxynitrides A, B and C (Figure 3 and Figure 4). These MgAlON compounds exhibit a complex TL peak at about $100{ }^{\circ} \mathrm{C}$ (for a heating rate of $1^{\circ} \mathrm{C} / \mathrm{s}$ ) which shifts to higher temperature when the nitrogen content increases (from A to C composition). For the sample A (low nitrogen content), the TL peak is relatively well resolved and its position coincides with the first TL peak observed on the $\mathrm{MgAl}_{2} \mathrm{O}_{4}$ sample. By analogy with the features of $\mathrm{MgAl}_{2} \mathrm{O}_{4}$, we assume that the $100{ }^{\circ} \mathrm{C} \mathrm{TL}$ peak observed in MgAlON could be due to the $\mathrm{Al}_{\mathrm{Mg}}{ }^{\vee}$ electron traps. The shift of the TL peak can be interpreted as the appearance of a new peak at about $150^{\circ} \mathrm{C}$ associated to the enhancement of nitrogen content in the MgAlON lattice. The negative charge of anionic site $\mathrm{N}_{O^{\prime}}$ could be responsible for the creation of $\mathrm{N}_{\mathrm{O}}$ ' hole traps in MgAlON solid solution.

The TL of A, B and C oxynitride compounds present mainly one large emission band which shifts from 692 to $740 \mathrm{~nm}$ with nitrogen content increasing (Figure 4). An emission line at $690 \mathrm{~nm}$ is observed only for the A compound. The disappearance of the line at $690 \mathrm{~nm}$ and the shifting of the emission band towards high wavelengths could be interpreted as a progressive decrease of the crystalline field around the $\mathrm{Cr}^{3+}$ site but, unfortunately, this trend is not confirmed by the fluorescence study.

\section{IV.3. Fluorescence results}

The excitation spectrum of the $700 \mathrm{~nm}$ emission of $\mathrm{MgAl}_{2} \mathrm{O}_{4}$ presents two maxima at 395 and $547 \mathrm{~nm}$. This result is in agreement with the observations of Tijaro and Ibarra [9] and coincides with the positions of excitation bands observed for $\mathrm{Al}_{2} \mathrm{O}_{3} / \mathrm{Cr}_{3}+$ [22]. These excitation bands at 395 and $547 \mathrm{~nm}$ are attributed to the ${ }^{4} \mathrm{~A}_{2} \rightarrow 4 \mathrm{~T}_{1}$ and ${ }^{4} \mathrm{~A}_{2} \rightarrow 4 \mathrm{~T}_{2}$ transitions of $\mathrm{Cr}^{3+}$ ion, respectively. In accordance with these results, the emission spectra of $\mathrm{Cr}^{3+}$ of these different samples were recorded at room temperature under excitation at $395 \mathrm{~nm}$ (Figure 5). Despite the weakness of the signal, two lines at 690 and $695 \mathrm{~nm}$ were observed in the emission spectrum of unannealed $\mathrm{MgAl}_{2} \mathrm{O}_{4}$ sample ( $\mathrm{S}_{3} \mathrm{OCr}$ ). These lines are labelled 1 and 2, respectively (Figure 5). The meaning of labels 1 and 2 will be justified in the last part of this paper. After annealing at $1450^{\circ} \mathrm{C}$ for $9 \mathrm{~h}$ under nitrogen flowing atmosphere, the emission spectrum of the reference compound $\mathrm{S} 3 \mathrm{OCr}$ was strongly enhanced (Figure 5). One relatively intense line at $690 \mathrm{~nm}$ and a group of weaker lines on each side $(677-700-709-719 \mathrm{~nm})$ were observed; they are labelled 1 . This behaviour is very similar to the one observed by Lapraz et al. [22] on single crystals of $\mathrm{Cr}^{3+}$ doped alumina. A very weak shoulder was also detected at about $695 \mathrm{~nm}$ (label 2). 
In Figure 6, we have reported the emission spectra of $\mathrm{A}, \mathrm{B}$ and $\mathrm{C}$ oxynitride compounds observed under $395 \mathrm{~nm}$ excitation. Some differences appear between the MgAlON solid solution spectrum and the $\mathrm{MgAl}_{2} \mathrm{O}_{4}$ one. The emission line $2(695 \mathrm{~nm})$ is enhanced and dominates in the spectra of $\mathrm{A}, \mathrm{B}$ and $\mathrm{C}$ materials. This emission line increases from $\mathrm{A}$ to $\mathrm{C}$ compounds, whereas line 1 remains unchanged in intensity. As a result, it appears reasonable to ascribe the increase of line 2 intensity to the increase of the nitrogen content.

A new energy level concept of $\mathrm{Cr}^{3+}$ in MgAlON solid solution can be proposed:

* line 1 (690 $\mathrm{nm}$ and others) and line 2 (695 nm) are related to the presence of $\mathrm{Cr}^{3+}$ ions substituted for $\mathrm{Al}$ in octahedral coordination; they correspond to ${ }^{2} \mathrm{E} \rightarrow{ }^{4} \mathrm{~A}_{2}$ transitions of $\mathrm{Cr}^{3+}$ in two distinct environments [23]. The position of line $1(690 \mathrm{~nm})$ is not affected by the presence of nitrogen corresponding to transitions in pure $\mathrm{CrO}_{6}$ site.

* the intensity of line $2(695 \mathrm{~nm})$ is perturbed by the oxygen/nitrogen substitution in $\mathrm{Al}$ $[\mathrm{ON}]_{6}$ in deformed octahedral site. This assumption is ascertained by the fact that $\mathrm{Cr}^{3+}$ ions are very sensitive to the crystalline field and that the $\mathrm{O} \leftrightarrow \mathrm{N}$ substitution causes a severe anionic distortion of the oxynitride lattice because the ionic radius of nitrogen is about 20\% larger than the one of oxygen ion. As a result, the crystal field strength of $\mathrm{Cr}^{3+}$ site is perturbed by the oxygen/nitrogen substitution and the wavelength of the ${ }^{2} \mathrm{E} \rightarrow 4 \mathrm{~A}_{2}$ transition is increased.

\section{IV.4. FTIR results}

The IR spectrum of $\mathrm{MgAl}_{2} \mathrm{O}_{4}$ (Figure 7) revealed two intense broad absorption bands near 700 and $520 \mathrm{~cm}^{-1}$. These two bands have been attributed to the stretching vibration of $\mathrm{AlO}_{6}$ octahedra and $\mathrm{MgO}_{4}$ tetrahedra, respectively [24]. IR spectra of $\mathrm{A}, \mathrm{B}$ and C compounds are shown in Figure 8. We note the presence of two broad bands corresponding to the vibration mode mentioned above. The $\mathrm{MgO}_{4}$ stretching vibration observed with the $\mathrm{A}, \mathrm{B}$ and $\mathrm{C}$ compounds appear at energies slightly higher (about $40 \mathrm{~cm}^{-1}$ ) than in $\mathrm{MgAl}_{2} \mathrm{O}_{4}$. On the other hand, in spite of the appearance of a small shoulder at about $920 \mathrm{~cm}^{-1}$, no significant difference occurs between the $\mathrm{AlO}_{6}$ stretching vibrations. The FTIR spectra of AlON- $\gamma$ and $\mathrm{Al}_{2} \mathrm{O}_{3}-\gamma$ (Figure 9) confirm that this shoulder is likely correlated to nitrogen presence.

\section{Conclusion}

The study of thermoluminescence and fluorescence characteristics of the spinel compounds of general formula $\mathrm{Mg}_{x} \mathrm{Al}_{y} \mathrm{O}_{4-z} \mathrm{~N}_{z}$ gives prominence to the role of thermoluminescence activator played by $\mathrm{Mn}^{2+}$ and $\mathrm{Cr}^{3+}$ ions respectively substituted for $\mathrm{Mg}$ (tetrahedral site) and for $\mathrm{Al}$ (octahedral site).

The compound $\mathrm{MgAl}_{2} \mathrm{O}_{4}(\mathrm{z}=0)$ exhibits two TL peaks at about 100 and $300{ }^{\circ} \mathrm{C}$. The first one is related to electrons release from $\left[\mathrm{Al}_{\mathrm{Mg}^{\circ}}{ }^{\circ}\right]$ traps, whereas the other TL peak is due to holes release from $\left[\mathrm{Mg}_{\mathrm{Al}}{ }^{\prime}\right]$.

The presence of nitrogen (compounds with $z>0$ ) is clearly observed by the disturbance produced in the emission spectrum of $\mathrm{Cr}^{3+}$ ions. This disturbance is interpreted as a consequence of the deformation of the octahedral site by the replacement of oxygen by some nitrogen in the $\mathrm{Cr}_{\mathrm{Al}}$ site environment.

\section{References}

[1] H.K. Jack. J. Mater. Sci. 11(1976), p. 1135.

[2] W. Sun, L. Ma and D. Yan. Chin. Sci. Bull. 35 (1990), p. 1189.

[3] R. Willems. J. Eur. Ceram. Soc. 12 (1993), p. 43.

[4] A. Granon, P. Goeuriot, F. Thevenot, J. Guyader, P. L'Haridon and Y. Laurent. J. Eur. Ceram. Soc. 13 (1994), p. 365

[5] A. Ibarra, D.F. Mariani and M. Jimenez de Castro. Phys. Rev., B 44 (1991), p. 12158.

[6] A. Ibarra, F.L. Lopez and M. Jimenez de Castro. Phys. Rev., B 44 (1992), p. 7256.

[7] A. Lorincz, M. Puma, F.J. James and J.H. Crawford. J. Appl. Phys. 53 (1982), p. 927.

[8] G.S. White, R.V. Jones and J.H. Crawford. J. Appl. Phys. 53 (1982), p. 265. 
[9] J.M.G. Tijero and A. Ibarra. J. Phys. Chem. Solids 54 (1993), p. 203.

[10] G.S. White, K.H. Lee and J.H. Crawford. Semicond. Insul. 5 (1980), p. 123.

[11] U.R. Rodriguez Mendoza, V.D. Rodriguez and A. Ibarra. Radiat. Eff. Defects Solids 136 (1995), p. 29.

[12] R.L. Mohler and W.B. White. J. Electrochem. Soc. 11(1995), p. 3923

[13] P.J. Deren, M. Malinowski and W. Strek. J. of Luminescence 68 (1996), p. 91.

[14] R. Devanathan, K.E. Sickafus, N. Yu and M. Nastasi. Philos. Mag. Lett. 72 (1995), p. 155.

[15] K.E. Sickafus, A.C. Larson, N. Yu, M. Nastasi, G.W. Hollenberg, F.A. Garner and R.C. Bradt. J. Nucl. Mater. 219 (1995), p. 128.

[16] A. Ibarra, R. Vila and F.A. Garner. J. Nucl. Mater. 233 (1996), p. 1336

[17] P.J. Deren, W. Strek, U. Oetliker and H.U. Gudel. Phys. Status Solidi 182 (1994), p. 241.

[18] N. Mironova, V. Skvortsova, A. Smirnovs and L. Cugunov. Opt. Mater. 6 (1996), p. 225.

[19] P. Goursat, P. Goeuriot, M. Billy, J.C. Labbe, J.M. Villechenoux, G. Roult and J. Bardolle. Mater. Chem. 6 (1981), p. 81.

[20] U. Smocker and F. Waldner. J. Phys. C. Solid State Phys. 9 (1976), p. 235.

[21] O. Morey, PhD thesis, St. Etienne, France, 2000.

[22] D. Lapraz, P. Iacconi, D. Daviller and B. Guilhot. Phys. Status Solidi, A 126 (1991), p. 521.

[23] Y. Tanabe and S. Sugano. J. Phys. Soc. Jpn. 9 (1954), p. 753.

[24] J. Parmentier, M. Richard-Plouet and S. Vilminot. Mater. Res. Bull. 33 (1998), p. 1717. 


\section{Figures}

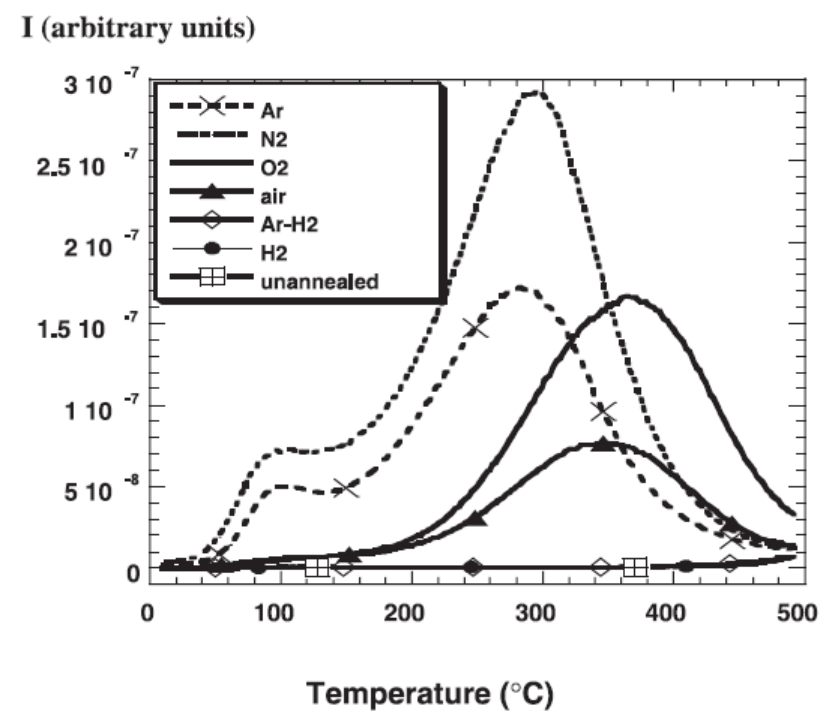

Figure 1: TL curves obtained after UV irradation at room temperature and readout at $1^{\circ} \mathrm{C} / \mathrm{s}$ on $\mathrm{MgAl}_{2} \mathrm{O}_{4}$ samples: unannealed or annealed under six different atmospheres.

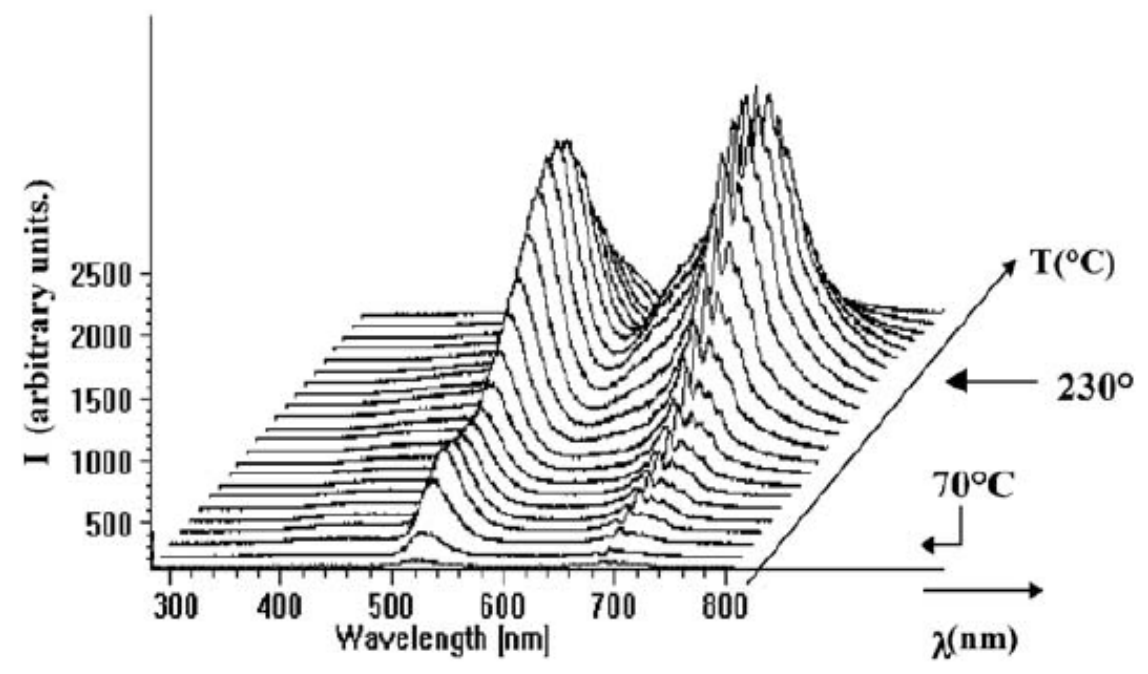

Figure 2: TL spectral analysis of $\mathrm{MgAl}_{2} \mathrm{O}_{4}$ sample annealed under nitrogen flowing atmosphere (heating rate of $\left.0.5^{\circ} \mathrm{C} / \mathrm{s}\right)$. 


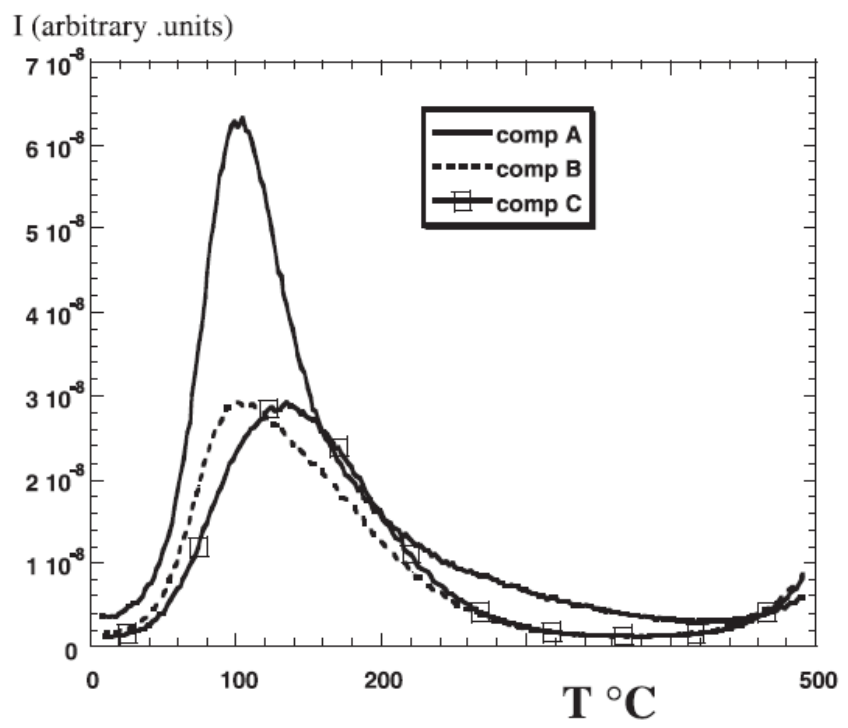

Figure 3: TL curves presented by the MgAlON samples A, B and C after UV irradiation at room temperature and heating rate of $1{ }^{\circ} \mathrm{C} / \mathrm{s}$. (These samples are synthesised at $145 \mathrm{O}^{\circ} \mathrm{C}-9 \mathrm{~h}$ under nitrogen static atmosphere.)
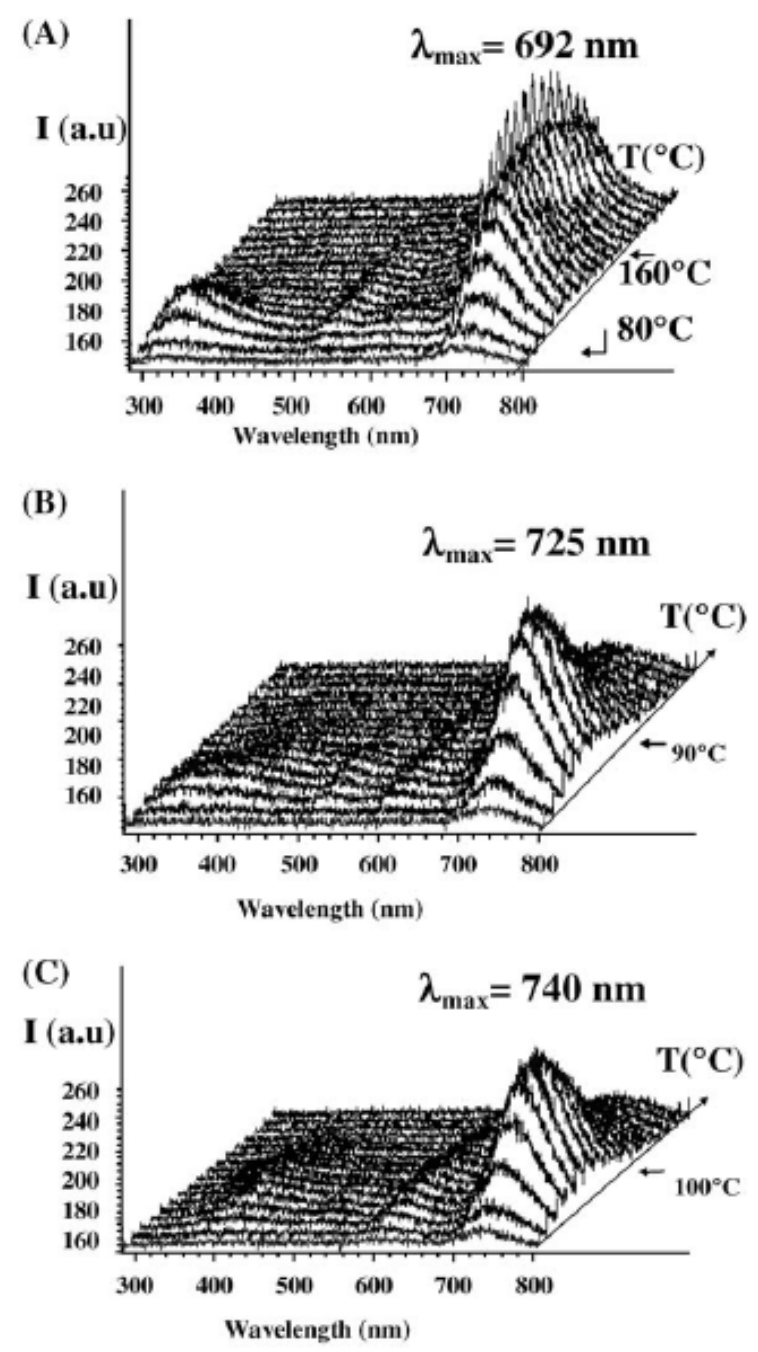

Figure 4: Spectral repartition of the three MgAlON compounds synthesised under nitrogen static atmosphere: A, $B, C$ recorded at $0.5{ }^{\circ} \mathrm{C} / \mathrm{s}$ (au: arbitrary units). 


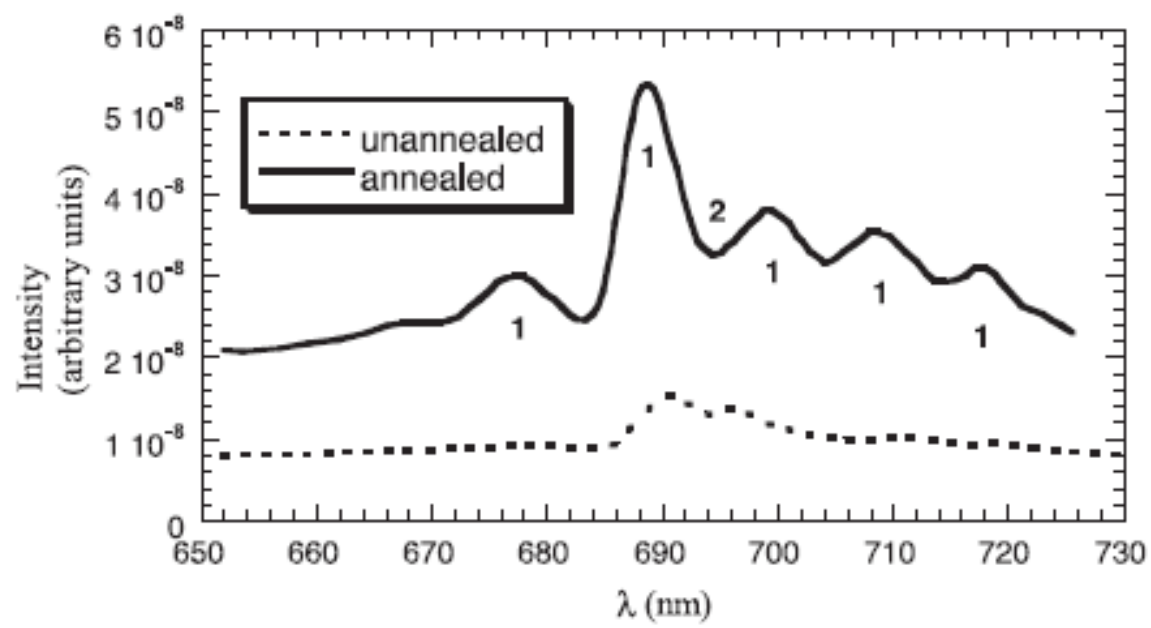

Figure 5: Emission spectra of $\mathrm{MgAl}_{2} \mathrm{O}_{4}$ obtained at room temperature $\left(\lambda_{\text {exc }}=395 \mathrm{~nm}\right)$ before and after neutral annealing.

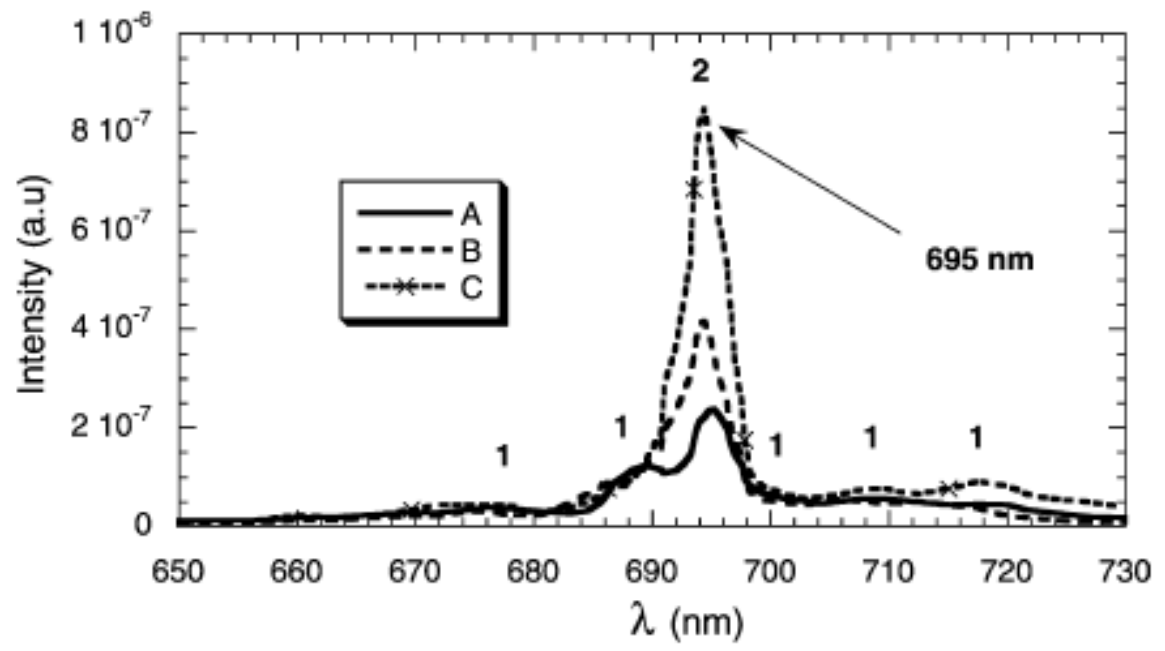

Figure 6: Emission spectra of the MgAlON compounds obtained at room temperature and irradiated at $395 \mathrm{~nm}$ (au: arbitrary units).

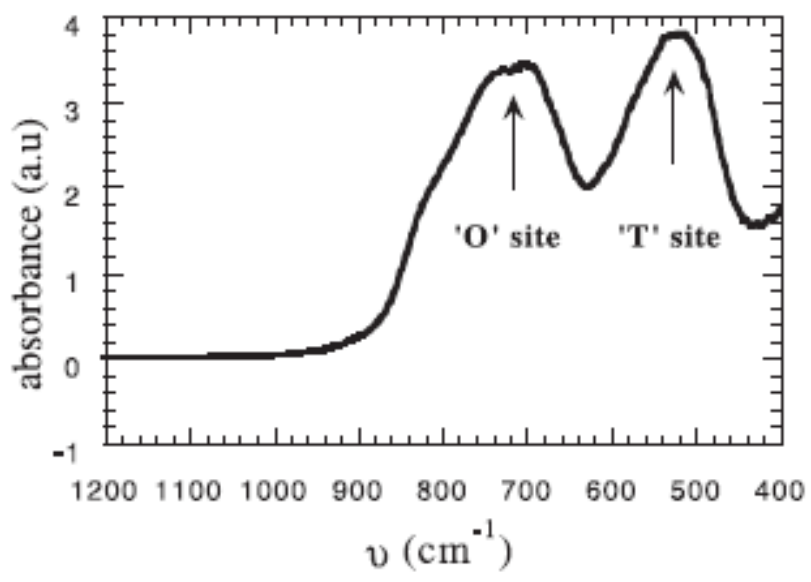

Figure 7: FTIR spectra of $\mathrm{MgAl}_{2} \mathrm{O}_{4}$ (au: arbitrary units). 
Solid State Ionics, 2003, 159(3-4), 381-388, doi:10.1016/So167-2738(o2)oo918-9

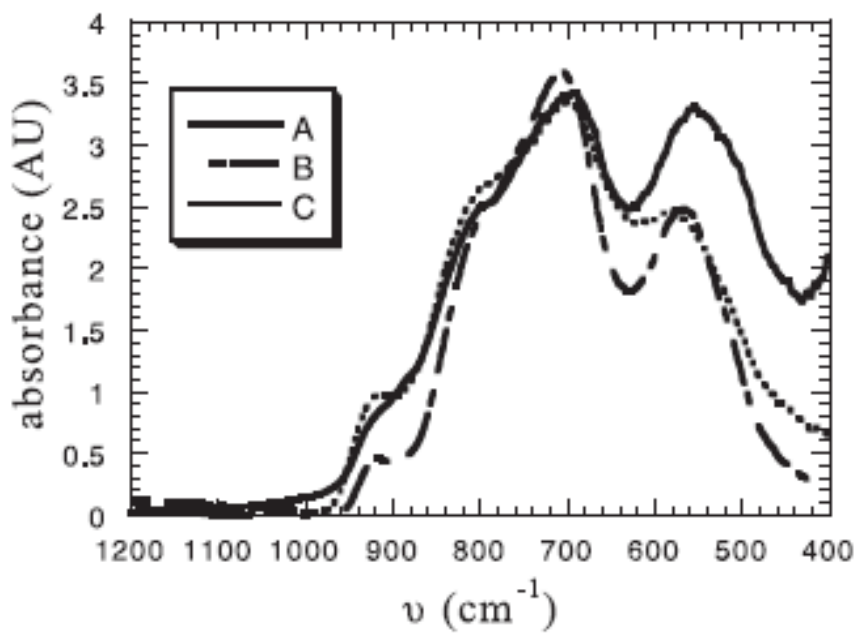

Figure 8: FTIR spectra of $A, B, C$ (au: arbitrary units).

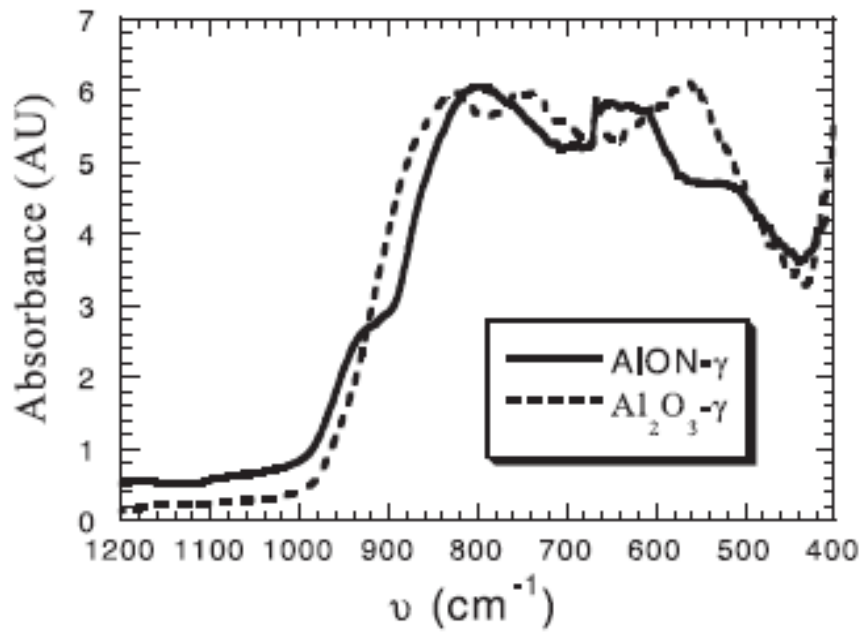

Figure 9: FTIR spectra of AlON- $\gamma$ and $\mathrm{Al}_{2} \mathrm{O}_{3}-\gamma$ (au: arbitrary units). 
Solid State Ionics, 2003, 159(3-4), 381-388, doi:10.1016/So167-2738(o2)oo918-9

\section{Tables}

Table 1: Starting compositions $A_{o}, B_{o}$, and $C_{o}$ before heat treatment

\begin{tabular}{|l|l|l|l|}
\hline Powders & $\mathrm{Al}_{2} \mathrm{O}_{3}(\mathrm{~mol} \%)$ & $\mathrm{AlN}(\mathrm{mol} \%)$ & $\mathrm{MgO}(\mathrm{mol} \%)$ \\
\hline $\mathrm{A}_{O}$ & 57 & 4 & 39 \\
\hline$B_{O}$ & 57 & 13 & 30 \\
\hline$C_{O}$ & 57 & 22 & 21 \\
\hline
\end{tabular}

Table 2: Characteristics of starting powders

\begin{tabular}{|l|l|l|l|l|}
\hline & AlN & $\mathrm{Al}_{2} \mathrm{O}_{3}$ & $\mathrm{MgO}$ & $\mathrm{Mg} \mathrm{Al}_{2} \mathrm{O}_{4}$ \\
\hline Name & Grade B & Cr6 & M3OCr & S3OCr \\
\hline Manufacter & Starck & Baïkowski & Baïkowski & Baïkowski \\
\hline $\begin{array}{l}\text { Specific surface } \\
\left(\mathrm{m}^{2} / g\right)\end{array}$ & 3.2 & 6.2 & 25.6 & 32.5 \\
\hline $\begin{array}{l}\text { Mean size }(\mu \mathrm{m}) \\
\text { Sedigraph) }\end{array}$ & 1.3 & 0.55 & 0.30 & 0.21 \\
\hline $\begin{array}{l}\text { Impurities } \\
\mathrm{N}\end{array}$ & & & & \\
\hline $\mathrm{O}$ & $34 \%$ & & & \\
\hline $\mathrm{C}$ & $1.6 \%$ & & & \\
\hline $\mathrm{Fe}$ & $0.07 \%$ & & & \\
\hline $\mathrm{Na}$ & $0.005 \%$ & $7 \mathrm{ppm}$ & $\mathrm{ppm}$ \\
\hline $\mathrm{K}$ & & $8 \mathrm{ppm}$ & & $23 \mathrm{ppm}$ \\
\hline $\mathrm{Si}$ & & $15 \mathrm{ppm}$ & & $12 \mathrm{ppm}$ \\
\hline $\mathrm{Ca}$ & & $34 \mathrm{ppm}$ & & $<1 \mathrm{ppm}$ \\
\hline
\end{tabular}

Table 3: Main impurities detected in the studied samples

\begin{tabular}{|l|l|l|l|l|}
\hline & Cr (ppm) & Mn (ppm) & Fe (ppm) & Ti (ppm) \\
\hline$A$ & 43 & $<10$ & 29 & $<10$ \\
\hline$B$ & 42 & $<10$ & 30 & $<10$ \\
\hline$C$ & 42 & $<10$ & 34 & $<10$ \\
\hline S3OCr & 38 & $<10$ & 19 & $<10$ \\
\hline
\end{tabular}


Solid State Ionics, 2003, 159(3-4), 381-388, doi:10.1016/So167-2738(o2)oo918-9

Table 4: Chemical formulations, lattice parameters $a_{o}$ and grain sizes of studied compositions $A, B, C$ and $S 30 C r$

\begin{tabular}{|c|c|c|c|c|}
\hline Composition & Formulation & $a_{\text {oexp }}(\mathrm{nm})$ & $a_{\text {ocal }}(\mathrm{nm})$ & Grain Size (nm) \\
\hline $\mathrm{S}_{3} \mathrm{OCr}$ & $\mathrm{MgO.969Al2.02104}$ & 0.8089 & 0.8084 & 220 \\
\hline$A$ & Mgo.726Al2.222O3.883No.117 & 0.8044 & 0.8053 & 400 \\
\hline$B$ & Mgo.538Al2.41903.667No.333 & 0.8026 & 0.8031 & 400 \\
\hline$C$ & Mgo.374Al2.551O3.598No.4O2 & 0.7993 & 0.8008 & 400 \\
\hline
\end{tabular}

The values of the aoxp parameter are measured (Fo.00O3 $\mathrm{nm}$ ) and compared to the a acalc values obtained from the equation developed in the text (Section 4). 